\title{
Determinants of Coconut Production in Large Scale Coconut Plantations in Sri Lanka: A Quantile Regression Approach
}

S.M.M. Samarakoon ${ }^{1}$, L.H.P. Gunaratne ${ }^{2}$ and H.L.J. Weerahewa ${ }^{2}$

\begin{abstract}
Large variability in yields and input usages have been evident in coconut plantations of Sri Lanka. The studies on the determinants of productivity of coconut lands mainly adopted Ordinary Least Square estimation which only provides overall effects at the mean. This study examines the determinants of land productivity in different land classes of coconut plantations using a Quantile Regression approach which allows the computation of the effect of each determinant in each quantile. Production functions of coconut were specified treating coconut yields as the dependent variable and bearing coconut palms, labor, fertilizer, agrochemicals, machinery usage, and rainfall as the independent variables in Cobb-Douglas form. Annual data from nine estates belong to Kurunegala Plantations Ltd. of Sri Lanka from 2000 to 2018 were used for the analysis. The results indicate that on average, fertilizer usage, agrochemical usage, number of bearing palms and rainfall have positive and significant effects on coconut production. It was found that OLS estimates underestimate and overestimate the input use efficiency at upper and lower quantiles respectively. Rainfall was found to be a significant factor in determining the coconut yield in each quantile except the $90^{\text {th }}$ quantile indicating that investments in irrigation which facilitates soil moisture improvement during dry periods would be important in improving the production. The application of fertilizer and other chemicals to the coconut lands in between the $60^{\text {th }}$ and the $90^{\text {th }}$ quantiles would be more effective. In contrast $Q R$ provided meaningful information at different segments in the production that enables to design appropriate structural policies steering the optimal use of inputs in coconut plantations.
\end{abstract}

Keywords: Quantile Regression, Coconut plantations, Rainfall, Fertilizer, Sri Lanka

1 Postgraduate Institute of Agriculture, University of Peradeniya, Sri Lanka. smmsamarakoon@gmail.com

${ }^{2}$ Department of Agricultural Economics and Business Management, Faculty of Agriculture, University of Peradeniya, Sri Lanka 


\section{Introduction}

Coconut, one of the leading plantation crops in Sri Lanka, plays a major role in the national economy, export earnings, and employment of the country. It is the second-highest demanding food of Sri Lankans after rice, the staple food, and accounts for 10 percent of total agricultural produce (EDB, 2017). Coconut occupies about 20 percent of the arable lands, almost 440,457 hectares (CSC, 2014). The current contribution of the coconut sector to Sri Lankan GDP is 0.7 percent (CBSL, 2019) and the contribution to export earnings is nearly five percent including both kernel and non-kernel products. Unlike the other two plantation crops, tea and rubber, where exports constitute over 90 percent of the output, the coconut industry caters to a substantial local consumption demand, leaving exports as a residual activity. In the early 1970s, the contribution of the coconut sector to GDP was around five percent and almost half of the coconut production was processed for exports. However, during the past few decades, the domestic demand for culinary nuts has largely increased due to rapid population growth thus reducing the exportable surplus of coconut.

The coconut lands in Sri Lanka are categorized into two distinct groups as smallholding sector (land extent is lower than 8 ha) and the estate sector (land extent is larger than $8 \mathrm{ha}$ ). According to this classification, the smallholding sector is approximately 82 percent of the total coconut land extent (CDA, 2019). Nevertheless, the aggregate extent under coconut at the national level has declined during the period from 1982 to 2002. Moreover, it is evident that the structure of the landholding size has shifted dramatically from plantation to small scale as a result of extensive land fragmentation that took place in the recent past especially in the coconut triangle where nearly two-thirds of the coconut lands are concentrated. Amidst the gradual decrease in the extent of coconut lands, a marginal increase can be observed in annual national coconut production, suggesting that the productivity of existing coconut lands has increased over time. Meanwhile, the per capita availability of coconut has been reduced over time indicating that the incremental coconut production is not sufficient to meet the domestic fresh coconut demand. On one hand, owing to the rising population the demand for culinary nuts has been increased. On the other hand, the kernel-based processing industry has been widening its scope to cater to the growing global demand, thus increasing the industrial demand for fresh nuts. Given the situation, the major challenge the coconut industry is facing at present is to increase the national production to cater to the growing demand of these two sub-sectors. Hence, overcoming the relative profitability of coconut production and increasing the surplus 
availability of coconuts for kernel-based processing industries have become important policy issues for Sri Lanka (Jayalath, 2018).

Similar to other coconut-producing countries, the coconut sector in Sri Lanka is competing with other land uses in attracting and retaining investment, and in justifying resources for maintaining the viability of existing coconut lands. Given the increasing competition for land, increasing the productivity of existing land (vertical expansion) is inevitable. However, analysis of past data indicates that the gap between the potential and the actual coconut yield in the estate sector has been widening over the years (i.e. 3 percent in 2001 to 9 percent in 2018) despite the technological advancement and the considerable emphasis placed on various subsidy programs in the coconut sector. Furthermore, large variability in yields and input usages has been evident in the coconut plantations of Sri Lanka.

Coconut is a rain-fed perennial crop and the coconut production may depend on many factors such as coconut variety, annual rainfall, age of the plantation, soil type, agro-ecological region, and management practices (i.e. fertilizer application, soil and moisture conservation, weed control, and pests and disease control). However, some of these factors may be beyond the control of the coconut grower, irrespective of the size of the holding and efforts to enhance land productivity. Fernando et al., 2007 have found that 60 percent of the variation in coconut production can be explained by climatic factors. Therefore, the productivity of coconut estates can only be enhanced through effective management practices and the attention to productivity gains arising from more efficient use of existing technology is justified.

In the empirical literature, a few farm-level studies on coconut plantations in Sri Lanka explore the technical relationship between the input and output of the coconut production process and productivity enhancement. Samarajeewa (2000) has estimated a production function in Cobb-Douglas form for coconut production by using time series data and found that rainfall and technology (i.e. research and development) are the most contributing factors for production increment at the aggregate level. In contrast, Mangika et al. (2009) and Jayalath et al. (2010) have found that labour and contract works have a significant positive effect on coconut production. Jayalath et al. (2010) have further stated that the minimum productive land size was 21 acres and the productivity of estates increases as the land size increases from 21 acres onwards up to 40 acres. Furthermore, coconut production is significantly associated with the land suitability class of coconut and the uses of recommended practices, when other biotic factors are non-limiting 
(Somasiri et al., 1994; Peries et al., 2001). Jayalath (2018) has estimated an empirical model based on the state-contingent production function, to examine how farmers manage coconut production uncertainty under different states of nature. Results revealed that the existing commercial production systems represent a set of flexible farming technologies which allows farm managers to better manage uncertain wet and dry states of nature.

It is important to note that the early empirical literature on the productivity of coconut lands is mainly based on Ordinary Least Square estimation of input-output relationships. OLS estimation focuses exclusively on the mean effects of productivity determinants and hence assumes the relationship between the covariates and response variable is constant at each quantile of the distribution. However, a plausible differential relationship at each quintile of the distribution can exit (Bernini et al., 2004; Gunewardena, 2006; Aturupana et al., 2008; Shaik, 2014). It is possible to evaluate the relationship between covariates and response variables at each quantile of the distribution with the introduction of Quantile Regression (QR) methods by Koenker and Bassett (1978). In general, QR proves to be extremely useful whenever one is interested in focusing on the relationship between the covariate and response variable at each quantile of the analyzed conditional distribution. Therefore, the objective of this study is to determine factors affecting land productivity in different land classes of coconut plantations using the $\mathrm{QR}$ approach by estimating the relationship between covariates (input quantities) and the response variable (output production) at each quantile of the distribution using primal production function. Furthermore, it is intended to compare the estimates generated from OLS and QR approaches to explore the effects of production determinants at different points of the conditional distribution of coconut production This study contributes to the novel literature in the way that comparing the effects of input use efficiency in perennial crops using two approaches (OLS and QR) in one study. The finding of the study is clear and worthy in the sense that providing useful insights for policymakers, specifically to design structural policies for the coconut sector of Sri Lanka. 


\section{Methodology}

In classical linear regression, we abandon the idea of estimating separate means for group data and assume that the means fall on a line, or and linear surface, and we estimate the parameters of a linear model. Least squares estimation provides a convenient method of estimating conditional mean models. Quantile Regression provides an equally convenient method for estimating models for conditional quantile functions (Koenker and Machado, 1999). Accordingly, applying the Ordinary Least Square (OLS) regression and Quantile Regression (QR) approaches to estimate the determinants of coconut production has been considered in this study.

Different functional forms can be applied in the context of agricultural production. Cobb Douglas production function (CD) is one of the most widely used functional forms due to its simplicity (Bhanumurthy, 2002). Hence, the study specifies a stochastic generalized $\mathrm{CD}$ functional form. The $\mathrm{CD}$ production function can be specified in log term as;

$$
\ln Q=\ln A+\sum \beta_{i} \ln x_{i}+U_{i}
$$

Where $Q$ is the output, $A$ is the technology, and $x_{i}$ denoted the inputs used in the production. $U_{i}$ is the error term.

The parameters of the specified production function were estimated at the conditional mean (using OLS) and at various quantiles (using QR). The quantile divides the population into nine parts. QR extends the estimation of conditional quantile function models in which quantiles of the conditional distribution of the response variable are expressed as a function of covariates (Roger, 2001). The Hausman test was used to decide between fixed or random-effect model which basically tests whether the unique errors $\left(U_{i}\right)$ are correlated with the regressors (Oscar, 2007).

\section{Theoretical Model}

The input-output relationship is often reduced to a production function (Koenker \& Bassett, 1978), and it represents the relationship between non-allocable inputs vectors used in the production of output. The output produced by inputs is described as; 


$$
y_{t}=f\left(x_{k, n t} \alpha_{k}, \varepsilon\right)
$$

Where $k=1 \ldots, K$ is the index of inputs, $n=1 \ldots, \mathrm{N}$ is the index of cross-sections and $t=1 \ldots, \mathrm{T}$ represents the index of years. The production function defined in equation (1) can be estimated using OLS by minimizing the sum of the square of errors concerning the parameter coefficients, $\alpha_{k}$ which provides standard OLS estimates for the conditional mean of output given input.

$$
\hat{\alpha}_{k}=\underset{\alpha_{k}}{\arg \min } \sum_{t}\left(y_{t}-x_{k, t} \alpha_{k}\right)^{2}
$$

In classical linear regression, separate means are not estimated for group data assuming that all these means fall on some linear surface. Thus, the parameters of the linear model are estimated.

The traditional OLS representation of production function in equation (1) and estimation of parameter coefficient in equation (2) are extended by Shaik (2014) to quantile presentation of parameter coefficient and production function in equations (3) and (4) respectively. Following Koenker and Bassett (1978), the conditional mean of output, $y_{t}$ given input, $x$ is extended to examine the parameter coefficients of exogenous covariates across the distribution of response or endogenous variable using $\mathrm{QR}$ techniques. Unlike OLS, QR minimizes the asymmetrically weighted sum of absolute errors and is represented as;

$$
\hat{\alpha}_{k}(\tau)=\min _{\xi_{p} \in R}\left\{\sum_{t \in\left\{n t: y_{t} \geq \xi_{p}\right\}} \tau\left|y_{t}-\xi_{p}\right|+\sum_{t \in\left\{t: y_{t} \leq \xi_{p}\right\}}(1-\tau)\left|y_{t}-\xi_{p}\right|\right\}
$$

Source: Shaik, 2014.

Where $\hat{\alpha}_{k}(\tau)$ is estimated for any quantile in the range of zero and one $(0,1)$ conditional on the covariates or exogenous variables. Equation (3) forms the basis for $\mathrm{QR}$ model specification with logarithmic inputs and output and is represented as;

$$
Q_{\tau}\left[y_{t} \mid x_{k, n t}\right]=\alpha_{0, \tau}+\alpha_{k, \tau} x_{k, n t}
$$

Source: Shaik, 2014. 
$Q_{\tau}\left[y_{t} / x_{k, n t}\right]$ is the quantile of output, $y_{t}$ conditional on covariate matrix, $x_{k, n t}$, which includes quantiles of inputs. The coefficient $\alpha_{k, \tau}$ represents the returns to covariates or information at the $\tau$ quantile.

\section{Empirical Model}

The empirical model was estimated by traditional OLS and QR using estate level data in the study without lag variables and with lag variables that are specified below in equations (5) and (6) respectively. According to past studies, the responsiveness of coconut production to some inputs like fertilizer and rainfall has proven the presence of lag effects (De Silva, 1972). Therefore appropriate lag variables were used in the model, where it is necessary to represent the characteristic nature of the coconut sector.

$$
\begin{aligned}
& \text { LnYi }=\alpha_{0}+\alpha_{1} \ln B C P_{t}+\alpha_{2} \ln L B O_{t}+\alpha_{3} \ln F E R_{t}+\alpha_{4} \ln C H E_{t}+\alpha_{5} \ln R A I N_{t}+\alpha_{6} \ln M A C_{t}+e \\
& \text { LnYi }=\alpha_{0}+\alpha_{1} \ln B C P_{t}+\alpha_{2} \ln L B O_{t}+\alpha_{3} \ln F E R_{t-2}+\alpha_{4} \ln C H E_{t}+\alpha_{5} \ln R A I N_{t-1}+\alpha_{6} \ln M A C_{t}+e
\end{aligned}
$$

Where $\operatorname{Ln}(Y i)$ is natural logarithm of the annual coconut production of the Kurunegala Plantations Ltd. is expressed as a function of natural logarithm of the number of bearing coconut palms $(\ln B C P)$, natural logarithm of labour usage $(\ln L B O)$, natural logarithm of fertilizer usage $(\ln F E R)$, natural logarithm of application of pesticides and weedicides $(\ln C H E)$, natural logarithm of rainfall $(\ln R A I N)$, and natural logarithm of machinery usage $(\ln M A C) . e$ is the random error term. Output is expressed in terms of the number of coconut nuts harvested per year. Fertilizer usage is used as the amount of fertilizer used (in $\mathrm{kg}$ ) in coconut cultivation. The number of labour days per year used for weeding, nut collection, mulching and fertilizer application is considered for the labour input. The annual average rainfall is expressed in millimeters $(\mathrm{mm})$. Tractor hours used per year are considered machinery usage in coconut production. In contrast, the quantity applied of weedicide and pesticides in liter per year is regarded as a chemical used for producing coconuts.

\section{Data Used}

The estate monitoring and evaluation division of Kurunegala Plantations Ltd. has maintained production and input data of the coconut plantations covering 4,700 ha. These panel data represent nine area estates belonging to Kurunegala Plantations Ltd. over 19 years from 2000 to 2018. The area estates are Attanagalla, Dambadeniya, 
Dodangaslanda, Hiriyala/Wariyapola, Dhathusenapura, Mahayaya, Katugampola, Kurunegala and Narammala.

\section{Results and Discussions}

The specified production functions in equations (5) and (6) were estimated by OLS and QR approaches. The descriptive statistics of the panel data used for the study are presented in Table 1.

Table 1: Summary statistics of the data

\begin{tabular}{|c|c|c|c|c|c|c|}
\hline Variable & Unit & $\begin{array}{l}\text { No. of } \\
\text { Observ. }\end{array}$ & Mean & SD & Min. & Max. \\
\hline $\begin{array}{l}\text { Coconut } \\
\text { production }\end{array}$ & $\begin{array}{l}\text { Nuts/ } \\
\text { ha/year }\end{array}$ & 171 & 4030.70 & 1389.04 & 953.88 & 7282.02 \\
\hline $\begin{array}{l}\text { Bearing } \\
\text { palms }\end{array}$ & Palms/ha & 171 & 97.60 & 30.59 & 21.94 & 176.07 \\
\hline Labour & $\begin{array}{l}\text { Man } \\
\text { days/ha/ } \\
\text { year }\end{array}$ & 171 & 54.38 & 19.71 & 9.65 & 111.69 \\
\hline Fertilizer & $\begin{array}{l}\mathrm{Kg} / \mathrm{ha} / \\
\text { year }\end{array}$ & 171 & 115.67 & 61.10 & 2.03 & 378.56 \\
\hline $\begin{array}{l}\text { Pesticides/ } \\
\text { weedicides }\end{array}$ & $\begin{array}{l}\text { liters/ha/ } \\
\text { year }\end{array}$ & 171 & 0.17 & 0.17 & 0.001 & 0.79 \\
\hline Rainfall & $\mathrm{mm} /$ year & 171 & 1903.17 & 920.13 & 400.5 & $5,886.80$ \\
\hline Machinery & $\begin{array}{l}\text { Tractor } \\
\text { hours/ha/ } \\
\text { year }\end{array}$ & 171 & 5.42 & 2.37 & 0.22 & 12.12 \\
\hline
\end{tabular}

At first, the study estimates the production function using both OLS and QR approaches without incorporating lag effects of the rainfall and fertilizer inputs. The estimates of the C-D production function with OLS and QR are presented in Table 2. Hausman's test revealed that the fixed effect model is appropriate for this analysis.

The OLS and QR estimation results of the production function with and without lag variables are given in Table 2 and Table 3 respectively. As shown in the tables, adjusted R-squared is high in OLS 
estimation than the pseudo-R-squared value in QR estimation ${ }^{3}$. Pseudo $\mathrm{R}$-squared cannot be interpreted independently or compared across data sets; they are valid and valuable in evaluating multiple models predicting the same outcome on the same data set. In other words, a pseudo-R-squared statistic without context has little meaning. A pseudo$\mathrm{R}$-squared only has meaning compared to another pseudo-R-squared of the same type, on the same data, predicting the same outcome (Koenker, 1999). Therefore, the production function estimated with lag variables by $\mathrm{QR}$ has a higher pseudo-R-squared than that of the estimation without lag variables indicating that the quantile with lag variables better predicts the outcome. In this estimate, some variables have more impacts at the upper quantiles.

Unlike traditional OLS, QR results provide parameter coefficients or input elasticity at each quantile, as shown in Table 2. The production function input elasticities obtained from the conventional OLS estimation indicated that only bearing palms are positive and statistically significant, where all the other variables are statistically insignificant. In the QR results, bearing palms are positive and statistically significant at all the quantiles. However, the effect of $10 \%$ additional rainfall has a positive $2.53 \%$ impact in estates at the $20^{\text {th }}$, $2.02 \%$ at the $30^{\text {th }}, 1.56 \%$ at the $70^{\text {th }}$, and $1.65 \%$ at the $80^{\text {th }}$ quantiles respectively. Further, QR results indicated that the effect of a $10 \%$ increase in fertilizer is expected to increase output by $1.32 \%$ in estates at the $10^{\text {th }}$ quantile and $1.26 \%$ in the $20^{\text {th }}$ quantile. Meanwhile, for estates at the $50^{\text {th }}, 60^{\text {th }}$ and $70^{\text {th }}$ quantiles, a $10 \%$ increase of input of chemicals is expected to increase output production by $0.34 \%, 0.33 \%$ and $0.32 \%$ respectively.

Previous studies have shown that the responsiveness of coconut production to inputs like fertilizer ranges between 3-5 years, and a 1-2year lag of rainfall influences new nut production (Peiris \& Thattil, 1997). Therefore, the lag effect of these variables was also included in the analysis. Table 3 presents QR parameter coefficients or input elasticity for each quantile ranging from the $10^{\text {th }}$ quantile to the $90^{\text {th }}$ quantile and OLS regression with one-year rainfall lag and two-year fertilizer application lag. As shown in Table 3, these estimates are considerably different than that of the previous estimation. Results reveal that the input elasticities obtained from the OLS indicate that

\footnotetext{
${ }^{3}$ The quantile analysis is more informative than OLS as they allow analyzing the model at the center and in the tails of the conditional distribution, and explaining variance about mean is not what QR. Hence, R-squared and Pseudo R-squared cannot be compared.
} 
bearing palms, rainfall, fertilizer, and pesticides/weedicides are positive and statistically significant.

According to the $\mathrm{QR}$ results, the number of bearing palms has a positive and statistically significant effect on coconut production across quantiles. Rainfall was also positive and statistically significant in all the quantiles except the $90^{\text {th }}$ quantile, and it is also linked to the fact that coconut is mainly grown as a rain-fed crop. It has been estimated that $60 \%$ of the variation in coconut production in Sri Lanka can be attributed to the climate variability under rain-fed conditions (Peiris et al., 1995). Therefore, increasing weather variability is becoming a significant source of uncertainty for the coconut industry in a changing climate. The female flower initiation stage of coconut is susceptible to water stress. As the interval between flower initiation and the harvesting of the mature fruit of coconut is 44 months, the effect of drought will reduce the nut yield at 3.5 years after the flower initiation. Even though there is a limited amount of reliable data on actual yield responses to irrigation, it has been reported that annual yield increases by $20-40$ nuts per palm in response to supplementary irrigation, and this yield increment will realize in the third and subsequent years after the introduction of irrigation (Carr, 2011) as irrigation increases female flower production and reduces premature nut fall. Thus, a supplement of irrigation whenever, prevailing inadequate rainfall, is crucial for productivity improvement of coconut lands even though the economic viability of irrigated coconut production is yet to be well established among the coconut producers.

Fertilizer was significant in the $60^{\text {th }}, 70^{\text {th }}, 80^{\text {th }}$, and $90^{\text {th }}$ quantiles, indicating that when coconut plantations reach a high level of productivity, it is essential to apply the required amount of fertilizer than estates that are at a low level of productivity. Also, chemicals were significant in the $20^{\text {th }}, 40^{\text {th }}, 60^{\text {th }}, 70^{\text {th }}, 80^{\text {th }}$, and $90^{\text {th }}$ quantiles implying that when plantations reach a high level of production, the application of pesticides/weedicides will reduce crop losses increase the yield. Therefore, site-specific management decisions are essential for obtaining optimum output in a particular plantation. 
Table 2: OLS and QR estimates of the production functions

\begin{tabular}{|c|c|c|c|c|c|c|c|c|c|c|c|}
\hline \multirow{2}{*}{$\begin{array}{l}\text { Independent } \\
\text { variable }\end{array}$} & \multirow{2}{*}{ Unit } & \multirow{2}{*}{ OLS } & \multicolumn{9}{|c|}{ Quantile Regression } \\
\hline & & & 0.1 & 0.2 & 0.3 & 0.4 & 0.5 & 0.6 & 0.7 & 0.8 & 0.9 \\
\hline Bearing Palms & $\begin{array}{l}\text { Number } \\
\text { of palms }\end{array}$ & $\begin{array}{c}0.9244 * * * \\
(0.000)\end{array}$ & $\begin{array}{c}0.9031 * * * \\
(0.000)\end{array}$ & $\begin{array}{c}0.8282 * * * \\
(0.000)\end{array}$ & $\begin{array}{c}0.9079 * * * \\
(0.000)\end{array}$ & $\begin{array}{c}0.9802 * * * \\
(0.000)\end{array}$ & $\begin{array}{c}0.9893 * * * \\
(0.000)\end{array}$ & $\begin{array}{c}0.9176^{* * * *} \\
(0.000)\end{array}$ & $\begin{array}{c}0.9447 * * * \\
(0.000)\end{array}$ & $\begin{array}{c}0.9709 * * * \\
(0.000)\end{array}$ & $\begin{array}{c}0.9808 * * * \\
(0.000)\end{array}$ \\
\hline Rainfall & $\mathrm{mm} /$ year & $\begin{array}{c}0.1151 \\
(0.111)\end{array}$ & $\begin{array}{l}0.2137 \\
(0.198)\end{array}$ & $\begin{array}{c}0.2535^{* *} \\
(0.041)\end{array}$ & $\begin{array}{c}0.2022 * \\
(0.060)\end{array}$ & $\begin{array}{l}0.1396 \\
(0.177)\end{array}$ & $\begin{array}{l}0.0936 \\
(0.257)\end{array}$ & $\begin{array}{c}0.1073 \\
(0.116)\end{array}$ & $\begin{array}{c}0.1558 * * \\
(0.045)\end{array}$ & $\begin{array}{c}0.1655^{*} \\
(0.073)\end{array}$ & $\begin{array}{l}0.1331 \\
(0.222)\end{array}$ \\
\hline Labor & $\begin{array}{l}\text { Person- } \\
\text { days/year }\end{array}$ & $\begin{array}{l}0.1422 \\
(0.792)\end{array}$ & $\begin{array}{r}-0.1072 \\
(0.389)\end{array}$ & $\begin{array}{r}-0.0249 \\
(0.787)\end{array}$ & $\begin{array}{l}0.0215 \\
(0.789)\end{array}$ & $\begin{array}{r}-0.0155 \\
(0.842)\end{array}$ & $\begin{array}{l}0.0279 \\
(0.652)\end{array}$ & $\begin{array}{l}0.0532 \\
(0.298)\end{array}$ & $\begin{array}{l}0.0076 \\
(0.895)\end{array}$ & $\begin{array}{l}0.0509 \\
(0.461)\end{array}$ & $\begin{array}{l}0.0054 \\
(0.947)\end{array}$ \\
\hline Fertilizer & $\mathrm{kg} /$ year & $\begin{array}{l}0.0289 \\
(0.362)\end{array}$ & $\begin{array}{c}0.1317 * \\
(0.073)\end{array}$ & $\begin{array}{c}0.1258 * * \\
(0.022)\end{array}$ & $\begin{array}{c}0.0649 \\
(0.170)\end{array}$ & $\begin{array}{l}0.0519 \\
(0.255)\end{array}$ & $\begin{array}{r}-0.0025 \\
(0.944)\end{array}$ & $\begin{array}{c}-0.0071 \\
(0.812)\end{array}$ & $\begin{array}{c}-0.0119 \\
(0.726)\end{array}$ & $\begin{array}{r}-0.0387 \\
(0.341)\end{array}$ & $\begin{array}{c}-0.0403 \\
(0.402)\end{array}$ \\
\hline $\begin{array}{l}\text { Pesticides/ } \\
\text { Weedicides }\end{array}$ & liters/year & $\begin{array}{l}0.0263 \\
(0.107)\end{array}$ & $\begin{array}{l}0.0002 \\
(0.955)\end{array}$ & $\begin{array}{l}0.0261 \\
(0.350)\end{array}$ & $\begin{array}{l}0.0213 \\
(0.379)\end{array}$ & $\begin{array}{l}0.0305 \\
(0.192)\end{array}$ & $\begin{array}{c}0.0339 * \\
(0.071)\end{array}$ & $\begin{array}{c}0.0327 * * \\
(0.035)\end{array}$ & $\begin{array}{c}0.0325^{*} \\
(0.064)\end{array}$ & $\begin{array}{l}0.0205 \\
(0.325)\end{array}$ & $\begin{array}{c}-0.0047 \\
(0.850)\end{array}$ \\
\hline Machinery & $\begin{array}{l}\text { tractor } \\
\text { hrs/ year }\end{array}$ & $\begin{array}{c}0.0139 \\
(0.790)\end{array}$ & $\begin{array}{l}0.0965 \\
(0.422)\end{array}$ & $\begin{array}{l}0.0522 \\
(0.559)\end{array}$ & $\begin{array}{r}-0.0122 \\
(0.874)\end{array}$ & $\begin{array}{r}-0.0339 \\
(0.650)\end{array}$ & $\begin{array}{r}-0.0309 \\
(0.605)\end{array}$ & $\begin{array}{c}0.0178 \\
(0.717)\end{array}$ & $\begin{array}{l}0.0335 \\
(0.549)\end{array}$ & $\begin{array}{l}0.0024 \\
(0.971)\end{array}$ & $\begin{array}{l}0.0434 \\
(0.582)\end{array}$ \\
\hline Constant & & $\begin{array}{c}2.9837 * * * \\
(0.000)\end{array}$ & $\begin{array}{l}1.7293 \\
(0.149)\end{array}$ & $\begin{array}{c}1.8478 * * \\
(0.039)\end{array}$ & $\begin{array}{c}2.1584 * * * \\
(0.006)\end{array}$ & $\begin{array}{c}2.5792 * * * \\
(0.001)\end{array}$ & $\begin{array}{c}3.0163 * * * \\
(0.000)\end{array}$ & $\begin{array}{c}3.1607 * * * \\
(0.000)\end{array}$ & $\begin{array}{c}2.9236^{* * * *} \\
(0.000)\end{array}$ & $\begin{array}{c}2.7721 * * * \\
(0.000)\end{array}$ & $\begin{array}{c}3.2449 * * * \\
(0.000)\end{array}$ \\
\hline $\begin{array}{l}\text { Adjusted } \mathrm{R}^{2} \\
\text { for OLS and } \\
\text { pseudo } \mathrm{R}^{2} \text { for } \\
\text { QR }\end{array}$ & & 0.927 & 0.844 & 0.792 & 0.749 & 0.719 & 0.699 & 0.666 & 0.642 & 0.611 & 0.587 \\
\hline
\end{tabular}

Source: Author's estimates. Notes: $* * *$ significant at $1 \%, * *$ significant at 5\%, ${ }^{*}$ significant at $10 \%$. p values are given in the parenthesis. 
Table 3: OLS and QR estimates with lag variables

\begin{tabular}{|c|c|c|c|c|c|c|c|c|c|c|c|}
\hline \multirow{2}{*}{$\begin{array}{l}\text { Independent } \\
\text { variable }\end{array}$} & \multirow{2}{*}{ Unit } & \multirow{2}{*}{ OLS } & \multicolumn{9}{|c|}{ Quantile Regression } \\
\hline & & & 0.1 & 0.2 & 0.3 & 0.4 & 0.5 & 0.6 & 0.7 & 0.8 & 0.9 \\
\hline $\begin{array}{l}\text { Bearing } \\
\text { Palms }\end{array}$ & $\begin{array}{l}\text { No of } \\
\text { palms }\end{array}$ & $\begin{array}{c}0.8516 * * * \\
(0.000)\end{array}$ & $\begin{array}{c}0.9254 * * * \\
(0.000)\end{array}$ & $\begin{array}{c}0.7563 * * * \\
(0.000)\end{array}$ & $\begin{array}{c}0.7919 * * * \\
(0.000)\end{array}$ & $\begin{array}{c}0.8472 * * * \\
(0.000)\end{array}$ & $\begin{array}{c}0.8180^{* * * *} \\
(0.000)\end{array}$ & $\begin{array}{c}0.7998 * * * \\
(0.000)\end{array}$ & $\begin{array}{c}0.7934 * * * \\
(0.000)\end{array}$ & $\begin{array}{c}0.8687 * * * \\
(0.000)\end{array}$ & $\begin{array}{c}0.9496 * * * \\
(0.000)\end{array}$ \\
\hline $\begin{array}{l}\text { Rainfall } \\
\text { (one-year } \\
\text { lag) }\end{array}$ & $\mathrm{mm} /$ year & $\begin{array}{c}0.2477 * * * \\
(0.001)\end{array}$ & $\begin{array}{c}0.4439 * * * \\
(0.001)\end{array}$ & $\begin{array}{c}0.3427 * * \\
(0.014)\end{array}$ & $\begin{array}{c}0.2949 * * \\
(0.017)\end{array}$ & $\begin{array}{c}0.1780 * \\
(0.057)\end{array}$ & $\begin{array}{c}0.1752 * \\
(0.051)\end{array}$ & $\begin{array}{c}0.2065^{* *} \\
(0.012)\end{array}$ & $\begin{array}{c}0.2358 * * * \\
(0.002)\end{array}$ & $\begin{array}{c}0.2215^{* *} \\
(0.018)\end{array}$ & $\begin{array}{l}0.1197 \\
(0.241)\end{array}$ \\
\hline Labor & $\begin{array}{l}\text { man- } \\
\text { days/year }\end{array}$ & $\begin{array}{l}0.0038 \\
(0.944)\end{array}$ & $\begin{array}{r}-0.0399 \\
(0.698)\end{array}$ & $\begin{array}{l}0.0902 \\
(0.381)\end{array}$ & $\begin{array}{l}0.0423 \\
(0.645)\end{array}$ & $\begin{array}{l}0.0107 \\
(0.878)\end{array}$ & $\begin{array}{l}0.0629 \\
(0.349)\end{array}$ & $\begin{array}{l}0.0640 \\
(0.292)\end{array}$ & $\begin{array}{l}0.0396 \\
(0.488)\end{array}$ & $\begin{array}{l}-0.0081 \\
(0.907)\end{array}$ & $\begin{array}{l}-0.0588 \\
(0.442)\end{array}$ \\
\hline $\begin{array}{l}\text { Fertilizer } \\
\text { (2-year lag) }\end{array}$ & $\mathrm{kg} /$ year & $\begin{array}{c}0.0613 * \\
(0.053)\end{array}$ & $\begin{array}{l}0.0851 \\
(0.152)\end{array}$ & $\begin{array}{l}0.0365 \\
(0.537)\end{array}$ & $\begin{array}{l}0.0469 \\
(0.375)\end{array}$ & $\begin{array}{l}0.0595 \\
(0.139)\end{array}$ & $\begin{array}{l}0.0560 \\
(0.147)\end{array}$ & $\begin{array}{c}0.0935 * * * \\
(0.008)\end{array}$ & $\begin{array}{c}0.0959 * * * \\
(0.004)\end{array}$ & $\begin{array}{c}0.0973^{* *} \\
(0.016)\end{array}$ & $\begin{array}{c}0.0892^{* *} \\
(0.044)\end{array}$ \\
\hline $\begin{array}{l}\text { Pesticides/ } \\
\text { Weedicides }\end{array}$ & litters/year & $\begin{array}{c}0.0293 * \\
(0.080)\end{array}$ & $\begin{array}{l}0.0135 \\
(0.667)\end{array}$ & $\begin{array}{l}0.0234 \\
(0.454)\end{array}$ & $\begin{array}{l}0.0304 \\
(0.277)\end{array}$ & $\begin{array}{c}0.0464 * * \\
(0.030)\end{array}$ & $\begin{array}{l}0.0306 \\
(0.134)\end{array}$ & $\begin{array}{c}0.0360 * \\
(0.052)\end{array}$ & $\begin{array}{c}0.0378 * * \\
(0.030)\end{array}$ & $\begin{array}{c}0.0419 * * \\
(0.048)\end{array}$ & $\begin{array}{c}0.0388 * \\
(0.096)\end{array}$ \\
\hline Machinery & $\begin{array}{l}\text { tractor } \\
\text { hrs/year }\end{array}$ & $\begin{array}{l}0.0742 \\
(0.211)\end{array}$ & $\begin{array}{l}0.0058 \\
(0.958)\end{array}$ & $\begin{array}{l}0.1621 \\
(0.146)\end{array}$ & $\begin{array}{l}0.1524 \\
(0.126)\end{array}$ & $\begin{array}{l}0.0640 \\
(0.395)\end{array}$ & $\begin{array}{l}0.0662 \\
(0.360)\end{array}$ & $\begin{array}{l}0.0494 \\
(0.450)\end{array}$ & $\begin{array}{l}0.0666 \\
(0.280)\end{array}$ & $\begin{array}{l}0.0331 \\
(0.659)\end{array}$ & $\begin{array}{l}0.0427 \\
(0.605)\end{array}$ \\
\hline Constant & & $\begin{array}{c}2.0268 * * * \\
(0.000)\end{array}$ & $\begin{array}{l}0.2035 \\
(0.838)\end{array}$ & $\begin{array}{l}0.9034 \\
(0.366)\end{array}$ & $\begin{array}{c}1.355 \\
(0.130)\end{array}$ & $\begin{array}{c}2.5520 * * * \\
(0.000)\end{array}$ & $\begin{array}{c}2.5004^{* * * *} \\
(0.000)\end{array}$ & $\begin{array}{c}2.2077 * * * \\
\quad(0.000)\end{array}$ & $\begin{array}{c}2.1676 * * * \\
\quad(0.000)\end{array}$ & $\begin{array}{c}2.2250 * * * \\
(0.001)\end{array}$ & $\begin{array}{c}2.7830 * * * \\
(0.000)\end{array}$ \\
\hline $\begin{array}{l}\text { Adjusted } \mathrm{R}^{2} \\
\text { for OLS and } \\
\text { Pseudo } \mathrm{R}^{2} \\
\text { for } \mathrm{QR}\end{array}$ & & 0.954 & 0.849 & 0.799 & 0.756 & 0.724 & 0.700 & 0.678 & 0.658 & 0.637 & 0.609 \\
\hline
\end{tabular}

Source: Author's estimates. Notes: $* * *$ significant at $1 \%, * *$ significant at $5 \%, *$ significant at $10 \%$ and $\mathrm{p}$ values are given in the parenthesis 


\section{Conclusions and Policy Implication}

This paper estimates production functions in Cobb Douglas functional form for coconut plantations using OLS and QR approaches. According to the results of OLS estimation, the number of bearing palms has a significant positive effect on coconut production when the input variables were considered without lags. When lag variables were considered in the production function, the number of bearing palms, one-year lag rainfall, fertilizer and pesticide/weedicides application were significantly affected. According to the QR results, the number of bearing palms and one-year lag rainfall positively impact nut production in every quantile except the $90^{\text {th }}$ quantile. Fertilizer input with a twoyear lag has a significant positive effect on coconut production in the $60^{\text {th }}, 70^{\text {th }}, 80^{\text {th }}$ and $90^{\text {th }}$ quantiles. Similarly, the application of pesticides and weedicides has a significant positive impact on nut production in the $40^{\text {th }}, 60^{\text {th }}, 70^{\text {th }}, 80^{\text {th }}$, and $90^{\text {th }}$ quantiles. Since quantile regression evaluates the relationship and the distribution of the dependent variable, it can be easily found out whether the relationship gets stronger or weaker over the distribution of coconut yield. Accordingly, the difference between OLS and QR regression estimates suggests that OLS underestimate and overestimate the proper relationship between covariates and response variable. The study contributes to the novel literature in the way that comparing the effects of input use efficiency in perennial crops using two approaches (OLS and QR) in one study.

Results of QR estimation reveal that the input use efficiency differs across the different quintiles of the distribution of the coconut plantations. Hence, the traditional measures of input use efficiency underestimated and overestimated at upper and lower quantiles. Accordingly, applying fertilizer and chemicals to the lands in between the $60^{\text {th }}$ and the $90^{\text {th }}$ quantiles is more effective, suggesting the importance of site-specific fertilizer recommendations. In addition, the use of weed and pest control measures will improve nut production in estates in upper quantiles. Moreover, supplementary irrigation is essential in productivity enhancement in coconut plantations, as rainfall is a significant and influential determinant throughout the entire distribution.

According to the results, it is evident that estimates of $\mathrm{QR}$ provide valuable information at different segments in the production to design appropriate structural policies steering the optimal input use in the coconut plantations. Furthermore, it is essential to note that the productivity decline experienced by the coconut sector has been further complicated by the changing climate while overshadowing the 
beneficial influence of the country's tropical climate favorable for coconut production. Therefore, the only long-term viable option to increase coconut production is to sustainably increase the productivity of coconut lands and increase the competitiveness of coconut production as land use. In this case, QR provides valuable insights to manage the existing coconut plantations more profitably.

However, the study uses data of nine estates that belong to the plantation sector. Therefore, extending this approach to the predominant smallholding sector is also essential to identify underline inefficiencies.

\section{References}

Aturupana, H., Deolalikar, A., \& Gunewardena, D. (2008). The determinants of child weight and height in Sri Lanka: A quantile regression approach (Research paper no. 2008/53). UNUWIDER.

Bernini, C., Freo, M., \& Gardini, A., (2004). Quantile estimation of frontier production function. Empirical Economics, 29, 373-381.

Bhanumurthy, K. V. (2002). Arguing a case for the Cobb-Douglas production function. Review of Commerce Studies, 75-91.

Carr, M. K. V. (2011). The water relations and irrigation requirements of coconut (Cocos nucifera): A review. Experimental Agriculture, 47, 27-51.

CBSL. (2019). Annual report. Central Bank of Sri Lanka.

CDA. (2019). Sri Lanka coconut statistics. Coconut Development Authority, Colombo, Sri Lanka.

CSC. (2014). Sri Lanka agricultural census. Department of Census and Statistics Colombo, Sri Lanka.

De Silva, M. A. T. (1972). Fertilizer experiments and coconut yield. Ceylon Coconut Planters' Review, 7, 92-94.

EDB. (2017). Annual report. Sri Lanka Export Development Board. 
Fernando, M. T. N., Zubair, L. M., Peiris, T. S. G., Ranasinghe, C. S., \& Ratnasiri, J. (2007). Economic value of climate variability impacts on coconut production in Sri Lanka. AIACC, 45, 1-9.

Gunewardena, D. (2006). Exploring gender wage gaps in Sri Lanka: A quantile regression approach [Paper presentation]. The $5^{\text {th }} \mathrm{PEP}$ Research Network General Meeting, Addis Ababa, Ethiopia.

Jayalath, K. V. N. N., Pathiraja, P. M. E. K., Jayasinghe-Mudalige, U. K., \& Fernando, M. T. N. (2010). An empirical investigation on the effect of land size on its productivity of coconut plantations in Sri Lanka. COCOS, 19, 67-75.

Jayalath, K. V. (2018). Weather variability and coconut production in Sri Lanka: State-contingent analysis [MPhil Thesis, The University of Queensland]. https://doi.org/10.14264/uq1.2018.759.

Koenker, R., \& Bassett, G. (1978). Regression quantiles. Econometrica, $46,33-50$.

Koenker, R., \& Machado, J. A. F. (1999). Goodness of fit and related inference process for quantile regression. Journal of the American Statistical Association, 94, 1296-1310.

Mangika, T. P. S., Jayasinghe, U. K., Jayalath, K. V. N. N., \& Pathiraja, P. M. E. K. (2009). Exploring the efficiency of coconut production in Sri Lanka: Where the lazy man's crop lies?. Proceedings of the Agricultural Research Symposium, Department of Agribusiness Management, Wayamba University of Sri Lanka, 43-48.

Oscar, T. S. (2007). Panel data analysis fixed and random effects using Stata. Data and Statistical Services, Princeton University.

Peiris, T. S. G., Thattil, R. O., \& Mahindapala, R. (1995). An analysis of the effect of climate and weather on coconut (Cocs nucifera L). Experimental Agriculture, 31, 451-460.

Peiris, T. S. G., \& Thattil, R. O. (1997). Assessment of the effects of environmental factors on yield of coconut (Cocos nucifera L.). COCOS, 12, 1-17. 
Peiris, T. S. G., Fernando, M. T. N., \& Waidyanatha, U. P. d. S. (2001). Factors influencing the productivity of coconut estates. Cord, 17(2), 1-9.

Roger, K., \& Kevin, F. H. (2001). Quantile regression. Journal of Economic Perspectives, 15(4), 143-156.

Samarajeewa, S. (2000). A production function approach in coconut cultivation. Sri Lanka Association for the Advancement of Science (SLASS).

Shaik, S. (2014). Re-examination of production, cost and restricted profit functions using quantile regression approach. Department of Agribusiness and Applied Economics, North Dakota State University, USA.

Somasiri, L. L. W., Nadarajah, N., Amarasinghe, L., \& Gunathilake, H. A. J. (1994, December). Land suitability assessment of coconut growing area in the coconut triangle. Occasional Publication Series (No.3, p. 90), Coconut Research Institute of Sri Lanka. 